\title{
Regulation and Binding Properties of S Fimbriae Cloned from E. coli Strains Causing Urinary Tract Infection and Meningitis
}

\author{
JOACHIM MORSCHHÄUSER ${ }^{1}$, VIKTORIA VETTER ${ }^{1}$, \\ TIMO KORHONEN ${ }^{2}$, BERNT ERIC UHLIN ${ }^{3}$, and JÖG HACKER ${ }^{1 *}$ \\ 1 Theodor-Boveri-Institut für Biowissenschaften, Lehrstuhl für Mikrobiologie, Univ. Würz- \\ burg, 8700 Würzburg, Germany \\ 2 Dept. of General Microbiology, Univ. of Helsinki, 00280 Helsinki, Finland \\ ${ }^{3}$ Dept. of Microbiol., Univ. of Umeå, 90187 Umeå, Sweden
}

With 2 Figures

\section{Summary}

$S$ fimbriae are able to recognize receptor molecules containing sialic acid and are produced by pathogenic $E$. coli strains causing urinary tract infection and menigitis. In order to characterize the corresponding genetic determinant, termed $\mathrm{S}$ fimbrial adhesin ( $\mathrm{ffa}$ ) gene cluster, we have cloned the $S$-specific genes from a urinary pathogen and from a meningitis isolate. Nine genes are involved in the production of $\mathrm{S}$ fimbriae, two of these, sfaB and sfaC code for regulatory proteins being necessary for the expression of $\mathrm{S}$ fimbriae. Two promoters, $P_{B}$ and $P_{C}$, are located in front of these genes. Transcription of the sfa determinant is influenced by activation of the promoters via $\mathrm{SfaB}$ and $\mathrm{SfaC}$, the action of the $\mathrm{H}-\mathrm{NS}$ protein and an RNaseE-specific mRNA processing. In addition, a third promoter, $\mathrm{P}_{\mathrm{A}}$, located in front of the major subunit gene sfaA, can be activated under special circumstances. Four genes of the sfa determinant code for the subunit-specific proteins, SfaA (16 kda), SfaG (17 $\mathrm{kda}), \mathrm{SfaS}(14 \mathrm{kda})$ and $\mathrm{SfaH}(29 \mathrm{kda})$. It was demonstrated that the protein SfaA is the major subunit protein while $S f a S$ is identical to the sialic-acid-specific adhesin of $S$ fimbriae. The introduction of specific mutations into sfaS revealed that a region of six amino acids of the adhesin which includes two lysine and one arginine residues is involved in the receptor specific interaction of $S$ fimbriae. Additionally, it has been shown that SfaS is necessary for the induction of fimbriation while SfaH plays a role in the stringency of binding of $S$ fimbriae to erythrocytes.

\section{Zusammenfassung}

S-Fimbrien können Sialinsäure-haltige Rezeptoren erkennen. Sie werden von pathogenen E. coli-Isolaten gebildet, die Harnwegsinfektionen oder Meningitiden auslösen können. Um die für S-Fimbrien kodierenden Gene zu bestimmen und zu charakterisieren, haben wir die

* Corresponding author 
$s f a($ („S fimbrial adhesin“)-Determinanten eines uropathogenen Stammes und eines Meningitis-Erregers kloniert. Neun Gene sind an der Produktion der S-Fimbrien beteiligt, zwei von diesen, $s f a B$ und $s f a C$, kodieren für Regulatorproteine, die für die Expression der S-Fimbrien notwendig sind. Zwei Promotoren $P_{C}$ und $P_{B}$ sind vor diesen Genen lokalisiert. Die Transkription der sfa Determinante wird durch die SfaB- und SfaC-spezifische Aktivierung der Promotoren, durch die Wirkung des H-NS Proteins und durch eine RNaseE abhängige mRNA-Prozessierung beeinflußt. Zusätzlich kann unter bestimmten Umständen ein dritter Promotor, $\mathrm{P}_{\mathrm{A}}$, der vor dem Hauptstrukturgen sfaA lokalisiert ist, aktiviert werden. Weiterhin kodieren vier Gene für die Proteinuntereinheiten SfaA (16 kda), SfaS (14 kda), SfaG (17 kda) und SfaH (29 kda). Es konnte gezeigt werden, daß das Protein SfaA identisch mit der Hauptstrukturuntereinheit der Fimbrien ist, während SfaS das Sialinsäurespezifische Adhäsin darstellt. Durch die Einführung von site-spezifischen Mutationen konnte eine aus sechs Aminosäuren bestehende Region von SfaS, die zwei Lysin- und einen Argininrest beinhaltet, für die Rezeptor-spezifische Interaktion von S-Fimbrien verantwortlich gemacht werden. Weiterhin wurde evident, daß SfaS an der Induktion der Fimbrienbildung beteiligt ist, während SfaH einen Einfluß auf die Stabilität der Bindung von S-Fimbrien an Erythrocyten hat.

\section{S Fimbrial Adhesins: Distribution and Role in Infectious Diseases}

$S$ fimbriae and $P$ fimbriae (also termed Pap - pili associated with pyelonephritis) represent the main adherence factors of extraintestinal $E$. coli strains $(16,29)$. The majority of strains isolated from urinary tract infections express $P$ fimbriae $(52,53)$. Sfimbrial adhesins are produced by a minority of uropathogenic $E$. coli strains and by $80 \%$ of isolates causing meningitis in newborns (NBM) $(18,28,31)$. S fimbriae bind to glycoproteins which terminate with the sequence $\alpha$-sialic acid- $(2-3)-\beta$-lactose $(17,35)$. Recent evidence exists that $S$ fimbriae also recognize carbohydrate structures of glycolipids (Kim, personal communication).

Only a limited number of $E$. coli isolates are able to express $S$ fimbriae: Strains with $\mathrm{O}$ antigen $\mathrm{O} 6$ and isolates of the serotypes $\mathrm{O} 2: \mathrm{K} 1, \mathrm{O} 18: \mathrm{K} 1$ and $\mathrm{O} 83: \mathrm{K} 1(3,34,53)$. The uropathogenic $\mathrm{O} 6$ strains are more frequently involved in infections of the bladder (cystitis) than those of the kidney (pyelonephritis; 49, 53). In contrast, $\mathrm{K} 1$ isolates are the main infectious agents causing cases of meningitis in newborns. These strains, however, have also been isolated from cases of pyelonephritis $(18,52)$.

$\mathrm{S}$ fimbriae together with F1C fimbriae and Sfr fimbriae form a special family of adherence factors, which are strongly related on the genetic level $(10,32,33,39,41)$. F1C and Sfr fimbriae, however, do not express an $\alpha$-sialic acid-(2-3)- $\beta$-lactose binding specificity and in contrast to $S$ fimbriae, they do not bind to erythrocytes $(50,51)$. While only limited information exists on the distribution of Sfr fimbriae, F1C fimbriae are expressed by about $30 \%$ of UTI strains of various serotypes including O18:K5, O6:K5 and O75:K5 (40).

There is no doubt that fimbrial adhesins play a key role in the initial colonization of bacteria on eukaryotic host tissues $(4,5) . S$ fimbriae are involved in the binding of bacteria to uroepithelial cells and to brain tissues $(19,23,36)$. Despite the fact that $S$ fimbriae exhibit a strong affinity to kidney cells $(20)$ and are involved in urinary tract infection in the experimental rat model $(21,22)$, their incidence among UTI strains is rather low in comparison to that of $P$ fimbriae (52). This may be a consequence of $S$ specific binding to the Tamm-Horsfall glycoprotein which may act as a trapping factor to eliminate $S$-fimbriated bacteria from urine (37). In addition, $S$ fimbriae are able to bind to endothelial cells and to a constituent of the extracellular matrix, laminin 
(Virkola et al., submitted). In addition, this particular attachment factor is involved in the activation of plasminogen to form plasmin which leads to fibrinolytic processes on tissues (38). The latter mechanism seems to be an important step in the pathogenesis of meningitis in newborns. Interestingly, human milk contains factors that specifically bind to S-fimbriated bacteria with the consequence of a protection of newborns against these potentially dangerous $E$. coli bacteria $(46-48)$.

\section{Overall Composition of the S-Fimbrial Adhesin (sfa) Determinant}

The sfa determinants were cloned from the chromosomes of two pathogenic $E$. coli isolates, the uropathogenic $E$. coli strain $536(06: \mathrm{K} 15)$ and the meningitis isolate IHE3034 (O18:K1) $(9,11,13)$. The determinant of strain 536 termed sfaI was fully sequenced and it became evident that nine genes were necessary for the production of $S$ fimbriae (45). As indicated in Fig. 1a, four genes, sfaA, sfaG, sfaS and sfa $\mathrm{H}$ code for the fimbrial subunits, being proteins of $16 \mathrm{kda}, 17 \mathrm{kda}, 14 \mathrm{kda}$, and $29 \mathrm{kda}$ which compose the fimbrial rod (42). While the protein SfaA represents the major subunit protein of $S$ fimbriae (42), the proteins SfaG, SfaS and SfaH are minor subunit proteins. In both cases (the sfal determinant and the sfaII gene cluster), the proteins SfaS are identical to the sialic-acid-specific adhesins $(17,24,43)$. In contrast to the SfaA and the SfaH proteins of the SfaI and Sfall complexes which show several amino acid exchanges in relation to each other, the SfaS proteins of both types of $S$ fimbriae are completely identical $(12,13)$.

Two genes, sfaB and $s f a \mathrm{C}$, are located at the $5^{\prime}$ end of the gene cluster and are necessary for the regulation of expression of the sfa determinant (see below). In addition, three genes, $s f a \mathrm{D}, s f a \mathrm{E}$, and $s f a F$ which code for proteins of $18 \mathrm{kda}, 24 \mathrm{kda}$ and 90 $\mathrm{kda}$ are part of the $s f a$ gene cluster. While a mutation in the gene sfaD does not affect fimbriation and hemagglutination of the corresponding clones, SfaE and SfaF are involved in the transport of the subunit proteins across the outer membrane (Morschbäuser et al., in preparation). Interestingly, SfaE exhibits homology to chaperone-like proteins of other fimbrial adhesin complexes while SfaF seems to be an outer membrane protein $(4,13)$.

\section{Transcription of the sfa Genes}

Using lamda-placMu fusion, three promotors, $\mathrm{pA}, \mathrm{pB}$ and $\mathrm{pC}$, could be identified in the $s f a$ determinant in front of the genes $s f a \mathrm{~A}, s f a \mathrm{~B}$ and $s f a \mathrm{C}$, respectively $(8,45)$. Transcriptional fusions with $p h o A$ and translational fusions with $l a c Z$ showed that the sfa genes were mainly transcribed from the two divergently oriented promotors, $\mathrm{pB}$ and $\mathrm{pC}$, and to a low degree, from $\mathrm{pA}$. To analyse the transcription of the sfa gene cluster in detail, we performed Northern blotting experiments with RNA from strains harbouring the cloned $s f a$ genes (26). One transcript of 500 bases encoding sfaC could be identified using an $s f a C$-specific probe. Another abundant transcript of 700 bases that codes for the main fimbrial subunit was detected using an $s f a A$-specific probe. In addition, an sfaBA bicistronic transcript of 1400 bases was seen in low amounts with both an sfaA-specific and an sfaB-specific probe (see Fig. 1b).

To localize the respective promotors exactly, we undertook primer extension studies with primers complementary to the $s f a \mathrm{~A}, s f a \mathrm{~B}$ and $s f a \mathrm{C} 5^{\prime}$ coding regions. The mRNA 

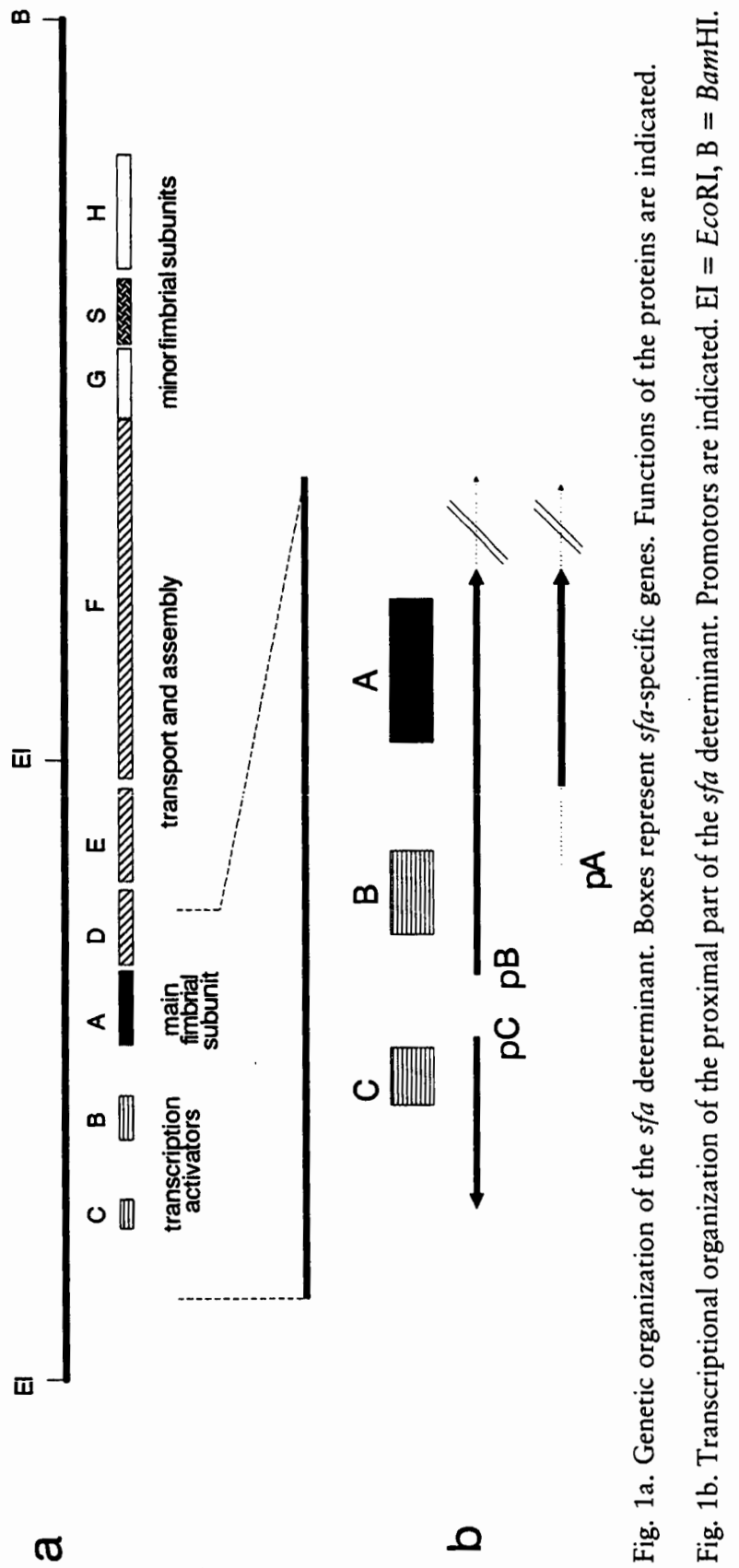
starting points identified in front of the genes $s f a \mathrm{~B}$ and $s f a C$ were in the correct position with respect to the predicted -10 and -35 regions of $E$. coli consensus promotors. The mRNA starting point in front of sfaA, however, did not reveal such homology (26). Further analysis showed that the sfaA mRNA starting point had not been a result of transcription initiation at this site but was produced by posttranscriptional cleavage of mRNAs starting at $\mathrm{pB}$ and $\mathrm{pA}$ (Morschbäuser et al., in preparation). The precursor transcripts were cleaved at two sites to yield a rapidly degraded $s f a B$ encoding part and a very stable $s f a \mathrm{~A}$-specific mRNA. As was recently shown also for the pap determinant $(1,2,27)$, this processing of the sfa transcript was dependent on the rne locus encoding or regulating RNaseE. In the RNaseE-negative mutant strain $\mathrm{N} 3431$, production of the 700 bases $s f a \mathrm{~A}$ transcript was strongly inhibited in comparison to the isogenic $m e^{+}$ strain N3433.

The rest of the sfa genes was also transcribed mainly from the proximal promotor $\mathrm{pB}$. These transcripts, when produced from the cloned wild type gene cluster, were too rapidly degraded to be detected by Northern hybridization. However, when transcriptional terminators stabilizing the mRNA's against nucleolytic attack by 3 ' exonucleases were inserted into the sfa determinant, longer transcripts starting at the second processing site in front of $s f a \mathrm{~A}$ demonstrated that the genes $s f a \mathrm{~B}$ to $s f a \mathrm{H}$ were presumably transcribed as a long polycistronic transcript, but most of the transcripts ended behind sfaA (Morschhäuser, unpublished).

\section{Regulation of sfa Expression by trans Acting Factors}

Fimbrial adhesin determinants are not expressed constitutively, rather, they are regulated by environmental signals $(6,30,44)$. In order to determine factors which influence the expression of the $s f a$ determinant, several mutations were introduced into the proximal region of the gene cluster to mutagenize the putative regulators, $\mathrm{SfaB}$ and $\mathrm{SfaC}$ (see 26,45 ). Mutations in $s f a \mathrm{~B}$ or $s f a C$ demonstrated that both gene products were indispensable for effective sfa expression from the wild type gene cluster. The mutations could be complemented by providing the genes on a compatible plasmid, indicating the trans activating role of $\mathrm{SfaB}$ and $\mathrm{SfaC}$ (26). A deletion of part of the intercistronic region between the two genes in plasmid pANN 81-5 resulted in $s f a$ expression that was to some degree independent of the activators. These results led us to the hypothesis that an unknown repressor might bind to the DNA region between $s f a \mathrm{~B}$ and $s f a C$, thus inhibiting $s f a$ expression in the absence of the activators. Examination of $s f a$ transcripts in the mutant strains by Northern hybridization showed that these regulatory effects were at the mRNA level (26).

An activator-independent sfa transcription could also be observed when different mutant $s f a$ derivatives were introduced into strain HMG 5 which has a mutation in $d r d \mathrm{X}$, the gene encoding the histone-like protein $\mathrm{H}-\mathrm{NS}$. The H-NS protein plays a role in the expression of several virulence factors (7). In the $d r d \mathrm{X}^{-}$strain, expression of the sfa genes was achieved even when both activators and the promoters $\mathrm{pC}$ and $\mathrm{pB}$ had been deleted, indicating an activation of the otherwise almost inactive promotor $\mathrm{pA}$ (plasmid pANN 81-2 in Table 1). These results suggest that $\mathrm{H}-\mathrm{NS}$ acts as a negative regulator of $s f a$ expression by inhibiting transcription from the sfa promoters and that $\mathrm{SfaB}$ and $\mathrm{SfaC}$ counteract this activity. 
Table 1. Effects of sfa mutations on hemagglutination capacity in $d r d \mathrm{X}^{+}$and $d r d \mathrm{X}^{-}$strains

\begin{tabular}{lll}
\hline Strain & Genotype & Hemagglutination' \\
\hline MC 1029 (pANN 801-13) & $\left(d r d \mathrm{X}^{+}, s f a \mathrm{C}^{+}, \mathrm{B}^{+}, \mathrm{A}-\mathrm{H}^{+}\right)$ & $1: 16$ \\
MC 1029 (pANN 81-2) & $\left(d r d \mathrm{X}^{+}, s f a \mathrm{C}^{-}, \mathrm{B}^{-}, \mathrm{A}-\mathrm{H}^{+}\right)$ & 0 \\
MC 1029 (pANN 81-3) & $\left(d r d \mathrm{X}^{+}, s f a \mathrm{C}^{+}, \mathrm{B1}, \mathrm{A}-\mathrm{H}^{+}\right)$ & 0 \\
MC 1029 (pANN 81-5) & $\left(d r d \mathrm{X}^{+}, s f a \mathrm{C}^{-}, \mathrm{B1}, \mathrm{A}-\mathrm{H}^{+}\right)$ & $1: 4$ \\
HMG 5 (pANN 801-13) & $\left(d r d \mathrm{X}^{-}, s f a \mathrm{C}^{+}, \mathrm{B}^{+}, \mathrm{A}-\mathrm{H}^{+}\right)$ & $1: 64$ \\
HMG 5 (pANN 81-2) & $\left(d r d \mathrm{X}^{-}, s f a \mathrm{C}^{-}, \mathrm{B}-\mathrm{A}-\mathrm{H}^{+}\right)$ & $1: 32$ \\
HMG 5 (pANN 81-3) & $\left(d r d \mathrm{X}^{-}, s f a \mathrm{C}^{+}, \mathrm{B1}, \mathrm{A}-\mathrm{H}^{+}\right)$ & $1: 32$ \\
HMG 5 (pANN 81-5) & $\left(d r d \mathrm{X}^{-}, s f a \mathrm{C}^{-}, \mathrm{B1}, \mathrm{A}-\mathrm{H}^{+}\right)$ & $1: 64$ \\
\hline
\end{tabular}

1 Determined by a quantitative hemagglutination assay.

\section{Genetic Studies on sfaS Coding for the S-Specific Adhesin}

The minor subunit protein $S f a S$ is able to recognize sialic acid crimmmus rupmor substances. In order to elucidate the S-specific binding properties of SfaS, a transcomplementation system with plasmids containing different origins of replication was developed. As demonstrated in Fig. 2, the introduction of the plasmid pMWW 50 carrying the gene sfaS under the control of an inducible promotor is able to restore the $S$ specific binding properties of SfaS-negative mutant clones. Interestingly, SfaS is able to mediate binding in clones expressing the major subunit $S$ fa $A$ and the minor subunits $\mathrm{SfaG}$ and $\mathrm{SfaH}$ and it also converts the non hemagglutinating $\mathrm{SfaA}^{+}, \mathrm{SfaG}^{-}, \mathrm{SfaS}^{-}$, SfaH ${ }^{-}$clone $\mathrm{HB101}$ (pMWW107) to a hemagglutination-positive strain.

The introduction of seven site-directed mutations in the sfaS sequence made it possible to identify an epitope involved in binding of the sialic-acid-specific adhesin. Table 2 indicates the phenotypes of the mutant clones. Only mutations introduced into the $C$ terminal part of the protein between amino acids 116 to 122 failed to agglutinate bovine red blood cells while amino acid exchanges affecting other regions of the

Table 2. Characterization of E.coli clones carrying site-specific mutations in the adhesin gene sfaS

\begin{tabular}{|c|c|c|c|}
\hline Plasmid & $\begin{array}{l}\text { Amino acid exchange } \\
\text { in } S f a S\end{array}$ & $\begin{array}{l}\text { Hemaggluti- } \\
\text { nation }\end{array}$ & Fimbriation ${ }^{2}$ \\
\hline $\begin{array}{l}\text { pANN 801-13 } \\
\text { pMWW 100/50 } \\
\text { pANN 801-116 } \\
\text { pANN 801-118 } \\
\text { pANN 801-122 } \\
\text { pANN 801-89 } \\
\text { pMWW 100/pMWW51 } \\
\text { pMWW 100/pMWW52 } \\
\text { pMWW } 100 / \mathrm{pMWW53}\end{array}$ & $\begin{array}{l}\text { wildtype } \\
\text { wildtype } \\
\text { Lys116 - Ser116 } \\
\text { Arg118 - Ser118 } \\
\text { Lys122 - Thr122 } \\
\text { Arg89 - Ile89 } \\
\text { Lys83 - Thr83 } \\
\text { Trp43 - Leu43 } \\
\text { Ala117 - Val117 }\end{array}$ & $\begin{array}{l}1: 32 \\
1: 32 \\
0 \\
0 \\
1: 32 \\
1: 16 \\
1: 16 \\
1: 32 \\
1: 16\end{array}$ & $\begin{array}{l}++++ \\
++++ \\
++++ \\
++++ \\
++++ \\
++++ \\
++ \\
+++ \\
++\end{array}$ \\
\hline
\end{tabular}

1 Determined by a quantitative hemagglutination assay.

2 Determined by electron microscopy. 

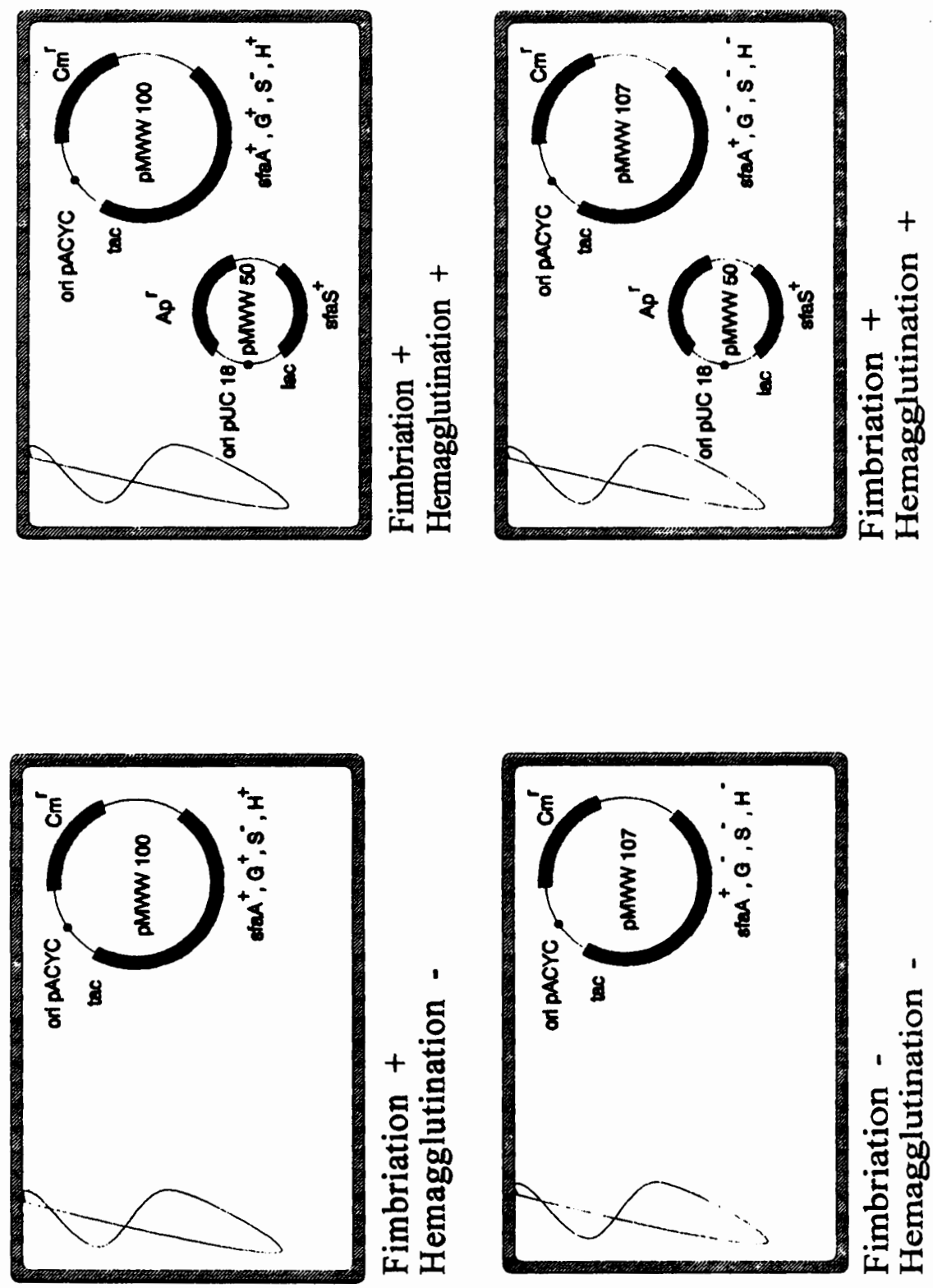
adhesin molecule had no influence on receptor-specific binding (see also 25). Interestingly, the region Lys ${ }^{16}$-Ala-Arg-Ala-Val-Ser-Lys ${ }^{122}$ revealed extensive homologies to epitopes located in other sialic-acid-specific proteins like $\mathrm{K} 99$ adhesin or the B subunits of the cholera toxin and the LT enterotoxin $(15,25)$.

\section{Functional Analysis of the Minor Subunit Proteins}

In previously published reports, sfaS-negative and $s f a H$-negative clones showed a definite reduction in fimbriation of recombinant clones $(23,25)$. It was therefore speculated that the SfaS and $\mathrm{SfaH}$ proteins played a role in the determination of $\mathrm{S}$ specific fimbriation. In contrast, an $s f a G$-negative mutant did not influence fimbriation of the cell but reduced the binding capacity of the corresponding clones. SfaG was therefore termed an "alternative“ binding protein (23). In order to prove whether or not the adhesin SfaS induced fimbriae formation, trans complementational tests with pMWW50 $\left(\mathrm{sfaS}^{+}\right)$were carried out (see Fig. 2). Following introduction of this plasmid into clones specific for $\mathrm{SfaA}^{+}, \mathrm{SfaG}^{+}, \mathrm{SfaS}^{-}$, and $\mathrm{SfaH}^{+}$, the degree of fimbriation of the bacteria increased dramatically. To our surprise, SfaS was also able to induce fimbriation following introduction into the non-fimbriated $\mathrm{SfaA}^{+}, \mathrm{SfaG}^{-}, \mathrm{SfaS}^{-}$, and $\mathrm{SfaH}^{-}$clones carrying plasmid pMWW107. From these data it can be concluded that the adhesive molecule, SfaS, plays an additional role in the biogenesis of fimbriae.

New data about $\mathrm{SfaH}$ strongly indicate that this molecule influences binding of the sfa complex to sialic-acid-containing receptor structures (13, Vetter, unpublished data). It was observed previously, that the UTI strain 536 exhibited a weaker binding to erythrocytes than the meningitis isolate $\operatorname{IHE} 3034(9,18)$. The same observation was made for the two sfa gene clusters, sfal and sfall, cloned from the chromosomes of the two strains. While the amino acid sequences of the two SfaS adhesins of SfaI and SfalI were identical (see above), the $\mathrm{SfaH}$ proteins showed seven amino acid exchanges. These alterations seem to control the differences in the binding capacity.

Table 3. Characterization of E. coli clones expressing different S fimbrial adhesin (Sfa) complexes

\begin{tabular}{llll}
\hline Strain/clone & sfa genotype & $\begin{array}{l}\text { Hemaggluti } \\
\text { nation }\end{array}$ & Fimbriation $^{2}$ \\
\hline HB101 (pANN 801-13) & $\begin{array}{l}\text { sfaA-I, sfaG-I } \\
\text { sfaS-I, sfaH-I }\end{array}$ & $1: 16$ & ++++ \\
HB101 (pAZZ 50) & $\begin{array}{l}\text { sfaA-II, sfaG-II } \\
\text { sfaS-II, sfaH-II } \\
\text { sfaA-II, sfaG-II } \\
\text { HB101 (pAZZ 50-67) }\end{array}$ & $1: 64$ & ++++ \\
& & - & ++ \\
\hline
\end{tabular}

1 Determined by a quantitative hemagglutination assay.

2 Determined by electron microscopy.

Acknowledgements. We wish to thank Manfred Ott (Würzburg) and Larry Phillips (Würzburg) for critical reading of the manuscript, and Herta Kurz (Würzburg) for editorial assistance. Our own work was supported by the Deutsche Forschungsgemeinschaft ( $\mathrm{Ha}$ 1434/1-7) and by the Fonds der Chemischen Industrie. 


\section{References}

1. Baga, M., M. Göransson, S. Normark, and B. E. Uhlin: Transcriptional activation of a Pap pilus virulence operon from uropathogenic Escherichia coli. EMBO J. 4 (1985) 3887-3893

2. Baga, M., S. Göransson, S. Normark, and B. E. Uhlin: Processed mRNA with different stability in the regulation of Escherichia coli pilin expression. Cell 52 (1988) 197-206

3. Blum, G., M. Ott, A. Cross, and J. Hacker: Virulence determinants of Escherichia coli O6 extraintestinal isolates analysed by Southern hybridizations and DNA long range mapping techniques. Microbial Pathogen. 10 (1991) 127-136

4. de Graaf, F. K.: Genetics of adhesive fimbriae of intestinal Escherichia coli. Curr. Top. Microbiol. Immunol. 151 (1990) 29-53

5. Finlay, B. B. and S. Falkow: Common themes in microbial pathogenicity. Microbiol. Rev. 53 (1989) 210-230

6. Göransson, M., K. Forsman, P. Nilsson, and B. E. Uhlin: Upstream activating sequences that are shared by two divergently transcribed operons mediate cAMP-CRP regulation of pilus-adhesin in Escherichia coli. Molec. Microbiol. 3 (1989) 1557-1565

7. Göransson, M., B. Sonden, P. Nilsson, B. Dagberg, K. Forsman, K. Emanuelsson, and $B$. E. Ublin: Transcriptional silencing and thermoregulation of gene expression in Escherichia coli. Nature 344 (1990) 682-685

8. Hacker, J.: Genetic determinants coding for fimbriae and adhesins of extraintestinal Escherichia coli. Curr. Top. Microbiol. Immunol. 151 (1990) 1-27

9. Hacker, J., G. Schmidt, C. Hughes, S. Knapp, M. Marget, and W. Goebel: Cloning and characterization of genes involved in production of mannose-resistant, neuraminidasesusceptible (X) fimbriae from a uropathogenic 06:K15:H31 Escherichia coli strain. Infect. Immun. 47 (1985) 434-440

10. Hacker, J., T. Schmoll, M. Ott, R. Marre, H. Hof, T. Jarchau, S. Knapp, I. Then, and W. Goebel: Genetic structure and expression of virulence determinants from uropathogenic E. coli strains. In: Kass, E. and C. Svanborg-Eden (eds.), Hostparasite interactions in urinary tract infections; Studies in infectious disease research, pp. 144-156. Univ. of Chicago Press, Chicago (1990)

11. Hacker, J., M. Ott, G. Blum, R. Marre, J. Heesemann, H. Tschäpe, and W. Goebel: Genetics of Escherichia coli uropathogenicity: Analysis of the O6:K15:H31 isolate 536. Zbl. Bakt. 276 (1992) 165-175

12. Hacker, J., J. Morschbäuser, M. Ott, and R. Marre: Molecular investigation of E. coli virulence in extraintestinal infections. In: Molecular recognition in hostparasite interactions (T. K. Korhonen, T. Hovi, and P. H. Mäkelä, eds.). Plenum Publ., New YorkLondon-Washington-Bosten (1992) in press

13. Hacker, J., H. Kestler, H. Hoschützky, K. Jann, F. Lottspeich, and T. K. Korhonen: Cloning and characterization of the S fimbrial adhesin II complex of an Escherichia coli 018:K1 meningitis isolate. Infect. Immun. 61 (1993), in press

14. Hultgren, S. J., S. Normark, and S. N. Abraham: Chaperone-assisted assembly and molecular architecture of adhesive pili. Annu. Rev. Microbiol. 45 (1991) 383-415

15. Jacobs, A. A., B. H. Simons, and F. K. de Graaf: The role of lysine-132 and arginine-136 in the receptor-binding domain of the K99 fibrillar subunit. EMBO J. 6 (1987) 1805-1808

16. Jann, $K$. and H. Hoschützky: Nature and organization of adhesins. Curr. Top. Microbiol. Immunol. 151 (1990) 55-70

17. Karlsson, K. A.: Animal glycosphingolipids as membrane attachment sites for bacteria. Annu. Rev. Biochem. 58 (1989) 309-350

18. Korbonen, T. K., M. V. Valtonen, J. Parkkinen, V. Väisänen-Rhen, J. Finne, F. Orskov, I. Orskov, S. B. Svenson, and P. H. Mäkelä: Serotype, hemolysin production and receptor recognition of Escherichia coli strains associated with neonatal sepsis and meningitis. Infect. Immun. 48 (1985) 486-491 
19. Korbonen, T. K., J. Parkkinen, J. Hacker, J. Finne, A. Pere, M. Rhen, and H. Holthöfer: Binding of Escherichia coli S fimbriae to human kidney epithelium. Infect. Immun. 54 (1986) 322-327

20. Korhonen, T. K., R. Virkola, B. Westerlund, H. Holthöfer, and J. Parkkinen: Tissue tropism of Escherichia coli adhesins in human extraintestinal infections. Curr. Top. Microbiol. Immunol. 151 (1990) 115-128

21. Marre, $R$, and J. Hacker: Role of S- and common type I fimbriae of Escherichia coli in experimental upper and lower urinary tract infection. Microbial Pathogen. 2 (1987) 223-226

22. Marre, R., J. Hacker, W. Henkel, and W. Goebel: Contribution of cloned virulence factors from uropathogenic $E$. coli strains to nephropathogenicity in an experimental rat pyelonephritis model. Infect. Immun. 54 (1986) 761-767

23. Marre, R., B. Kreft, and J. Hacker: Genetically engineered S and F1C fimbriae differ in their contribution to adherence of Escherichia coli to cultered renal tubular cells. Infect. Immun. 58 (1990) 3434-3437

24. Moch, T., J. Hoschützky, J. Hacker, K. D. Krönke, and K. Jann: Isolation and characterization of the $\alpha$-sialyl- $\beta$-2,3-galactosyl-specific adhesin from fimbriated Escherichia coli. Proc. Natl. Acad. Sci. USA 84 (1987) 3462-3466

25. Morschbäuser, J., H. Hoschützky, K. Jann, and J. Hacker: Functional analysis of the Sialic acid-binding adhesin SfaS of pathogenic Escherichia coli by site-specific mutagenesis. Infect. Immun. 58 (1990) 2133-2138

26. Morschbäuser, J., B. E. Uhlin, and J. Hacker: Transcriptional analysis and regulation of the sfa determinant coding for $S$ fimbria of pathogenic $E$. coli strains. Molec. Gen. Genet. (1993), in press

27. Nilsson, P. and B. E. Ublin: Differential decay of a polycistronic Escherichia coli transcript is initiated by RNase E-dependent endonucleolytic processing. Molec. Microbiol. 5 (1991) 1791-1799

28. Ørskov, I. and F. Ørskov: Escherichia coli in extraintestinal infections. J. Hyg. (Camb.) 95 (1985) 551-575

29. Ørskov, I. and F. Ørskov: Serologic classification of fimbriae. Curr. Top. Microbiol. Immunol. 151 (1990) 71-90

30. Ott, M. and J. Hacker: Analysis of the variability of S fimbriae expression in an Escherichia coli pathogen. FEMS Microbiol. Lett. 79 (1991) 233-238

31. Ott, M., J. Hacker, T. Schmoll, T. Jarchau, T. K. Korhonen, and W. Goebel: Analysis of the genetic determinants coding for the $\mathrm{S}$ fimbrial adhesin $(s f a)$ in different Escherichia coli strains causing meningitis or urinary tract infections. Infect. Immun. 54 (1986) 646-653

32. Ott, M., T. Schmoll, W. Goebel, I. Van Die, and J. Hacker: Comparison of the genetic determinant coding for the S-fimbrial adhesin (sfa) of Escherichia coli to other chromosomally encoded fimbrial determinants. Infect. Immun. 55 (1987) 1940-1943

33. Ott, M., H. Hoschützky, K. Jann, I. Van Die, and J. Hacker: Gene clusters for S fimbrial adhesin (sfa) and F1C Fimbriae (foc) of Escherichia coli: Comparative aspects of structure and function. J. Bact. 170 (1988) 3983-3990

34. Ott, M., L. Bender, G. Blum, M. Schmittroth, H. Tschäpe, and J. Hacker: Virulence patterns and long rang mapping of extraintestinal Escherichia coli $\mathrm{K} 1, \mathrm{~K} 5$ and $\mathrm{K} 100$ isolates: use of the pulsed field gel electrophoresis technique. Infect. Immun. 59 (1991) 2614-2674

35. Parkkinen, J., B. N. Rogers, T. Korbonen, W. Dabr, and J. Finne: Identification of the O-linked sialyl oligosaccharides of glycophorin A as the erythrocyte receptors for Sfimbriated Escherichia coli. Infect. Immun. 54 (1986) 37-42

36. Parkkinen, J., T. K. Korhonen, A. Pere, J. Hacker, and S. Soinila: Binding sites in the rat brain for Escherichia coli $\mathrm{S}$ fimbriae associated with neonatal meningitis. J. Clin. Invest. 81 (1988a) 860-865 
37. Parkkinen, J., R. Virkola, and T. K. Korhonen: Identification of factors in human urine that inhibit the binding of Escherichia coli adhesins. Infect. Immun. 56 (1988b) 2623-2630

38. Parkkinen, J., J. Hacker, and T. Korhonen: Acceleration of tissue plasminogen activator-catalized plasminogen activation by Escherichia coli S fimbriae associated with neonatal septicaemia and meningitis. Thromb. Haematosis 65 (1991) 483-486

39. Pawelzik, M., J. Heesemann, J. Hacker, and W. Opferkuch: Cloning and characterization of a new type of fimbria (S/F1C related fimbria) expressed by an Escherichia coli O75:K1:H7 blood culture isolate. Infect. Immun. 56 (1988) 2918-2924

40. Pere, A., B. Nowicki, H. Saxen, A. Siitonen, and T. K. Korbonen: Expession of P, type I and Type IC fimbriae of Escherichia coli in the urine of patients with acute urinary tract infection. J. Infect. Dis. 156 (1987) 567-574

41. Riegman, N., R. Kusters, H. van Veggel, Bergmans, P. van Bergen en Henegouwen, J. Hacker, and I. van Die: F1C fimbriae of a uropathogenic Escherichia coli: Genetic and functional organization of the foc gene cluster and identification of minor subunits. J. Bact. 172 (1990) 1114-1120

42. Schmoll, T., J. Hacker, and W. Goebel: Nucleotide sequence of the sfaA gene coding for the S fimbrial protein subunit of Escherichia coli. FEMS Microbiol. Lett. 41 (1987) 229-235

43. Schmoll, T., H. Hoschützky, J. Morschhäuser, F. Lottspeich, K. Jann, and J. Hacker: Analysis of genes coding for the sialic acid-binding adhesin and two other minor fimbrial subunits of the S-fimbrial adhesin determinant of Escherichia coli. Molec. Microbiol. 3 (1989) 1735-1744

44. Schmoll, T., M. Ott, B. Oudega, and J. Hacker: Use of a wild-type gene fusion to determine the influence of environmental conditions on expression of the $S$ fimbrial adhesin in an Escherichia coli pathogen. J. Bact. 172 (1990a) 5103-5111

45. Schmoll, T., J. Morschbäuser, M. Ott, B. Ludwig, I. van Die, and J. Hacker: Complete genetic organization and functional aspects of the Escherichia coli $\mathrm{S}$ fimbrial adhesin determinant: nucleotide sequence of the genes $s f a B, C, D, E, F$. Microbial Pathogen. 9 (1990b) 331-343

46. Schroten, H., F. G. Hanisch, R. Plogmann, J. Hacker, G. Uhlenbruck, and V. Wahn: Inhibition of an Adhesion of S-fimbriated Escherichia coli to buccal epithelial cells by human milk fat globule membrane components: a novel aspect of protective function of mucins in the non-immunoglobulin fraction. Infect. Immun. 60 (1992a) 2893-2899

47. Schroten, H., R. Plogmann, F. G. Hanisch, J. Hacker, R. Nobis-Bosch, and V. Wahn: Inhibition of adhesion of S-fimbriated $E$. coli to buccal epithelial cells by human skim milk is predominantly mediated by mucins and depends on the period of lactation. Acta Paetr. scand. (1992) in press

48. Schroten, H., A. Lethen, F. G. Hanisch, R. Plogmann, J. Hacker, R. Nobis-Bosch, and V. Wahn: Inhibition of adhesion of S-fimbriated Escherichia coli to epithelial cells by meconium, feces of breast fed and formula fed newborns - mucins are the major inhibitory component. J. Pediatr. Gastroenterol. Nutr. 15 (1992c) 150-158

49. Tschäpe, H., H. Steinrück, P. Buchbolz, R. Prager, E. Tietze, G. Seltmann, and J. Hacker: Molecular analysis of Escherichia coli from neonatal infections and its epidemiological implication. In: Research in perinatal medicine (E. L. Grauel, L. Stern, I. Syllm-Papoport, and R. R. Wauer, eds.), pp. 446-452. Verlag Gesundheit, Berlin (1990)

50. Van Die, I., C. Kramer, J. Hacker, H. Bergmans, W. Jongen, and W. Hoekstra: Nucleotide sequence of the genes coding for minor fimbrial subunits of the F1C fimbriae of Escherichia coli. Res. Microbiol. (Inst. Pasteur) 142 (1991) 653-658

51. Virkola, R., B. Westerlund, H. Holthöfer, J. Parkkinen, M. Kekomäki, and T. K. Korhonen: Binding characteristics of Escherichia coli adhesins in human urinary bladder. Infect. Immun. 56 (1988) 2615-2622 
52. Väisänen-Rhen, V., J. Elo, E. Väisänen, A. Siitonen, I. Orskov, F. Orskov, S. B. Svenson, P. H. Mäkelä, and T. K. Korhonen: P-fimbriated clones among uropathogenic Escherichia coli strains. Infect. Immun. 43 (1984) 149-155

53. Zingler, G., M. Ott, G. Blum, U. Falkenhagen, G. Naumann, W. Sokolowska-Köhler, and J. Hacker: Clonal analysis of Escherichia coli serotype 06 strains from urinary tract infections. Microbial Pathogen. 12 (1992) 299-310

Professor Dr. Jörg Hacker, Theodor-Boveri-Institut für Biowissenschaften, Lehrstuhl für Mikrobiologie, Röntgenring 11, D-8700 Würzburg

With

Sun

Bor

tors cc

chemic

This $b$

proteir

BvgA :

factors

identif

factors

comple

tion of

there $n$

and th

Zus

Der

koordi

lien. E

Locus

tionsak

BvgA y

sion el

tifizien

des Per

oder $m$

die $\mathrm{Re}$

diniert

der $\mathrm{Fal}$ 